\title{
Micropropagation of Alocasia amazonica using semisolid and liquid cultures
}

\author{
E. A. Jo • H. N. Murthy • E. J. Hahn • K. Y. Paek
}

Published online: 29 February 2008

(C) The Society for In Vitro Biology 2008

Erratum to: In Vitro Cell.Dev.Biol.-Plant

DOI 10.1007/s11627-007-9081-2

The first author's name should read E. A. Jo. This article was published in Vol. 44, No. 1, pp. 26-32.

The online version of the original article can be found at http://dx.doi. org/10.1007/s11627-007-9081-2.

E. A. Jo $\cdot$ H. N. Murthy $\cdot$ E. J. Hahn $\cdot$ K. Y. Paek $(\bowtie)$

Research Center for Development of Advanced Horticultural

Technology, Chungbuk National University,

Cheongju 361-763, South Korea

e-mail: paekky@chungbuk.ac.kr

H. N. Murthy

Department of Botany, Karnatak University,

Dharwad 580 003, India 